\title{
Biomechanical behavior of indirect composite materials: a 3D-FEA study
}

\author{
Comportamento biomecânico de resinas compostas indiretas: um estudo 3D-FEA
}

João Paulo Mendes TRIBST ${ }^{1}$, Amanda Maria De Oliveira DAL PIVA ${ }^{1}$, Alexandre Luiz Souto BORGES ${ }^{1}$

1 - São Paulo State University (Unesp) - Institute of Science and Technology - São José dos Campos - Department of Dental Materials and Prosthodontics - SP - Brazil.

\begin{abstract}
Objetivo: This study aimed to evaluate the influence of the elastic modulus of indirect composite resins (ICR) in the stress distribution of a restored maxillary first premolar. Material and methods: A three-dimensional (3D) finite element model of the tooth and the mesialocclusal-distal (MOD) restoration was created. Three ICR were simulated, by changing the elastic modulus: 10, 15 and $20 \mathrm{GPa}$. All materials were considered as isotropic, homogeneous and linearly elastic. An occlusal load (200 N) was applied on occlusal surface trough a sphere, and the nodes of the external surface of the root were fixed. The maximum principal stresses on the tooth and restoration were analyzed. Results: According to FE analysis, the lower the ICR elastic modulus, the higher the tensile stress values generated on the remaining tooth. For the restoration, the opposite was observed: the lower the modulus, the lower the tensile stress. Conclusion: With the limitations of this study it is possible to conclude that the greater the elastic modulus of the restorative material the harder it will be to deflect the cusps, but the easier the fracture of the resin.
\end{abstract}

\section{KEYWORDS}

Finite Elements Analysis; Composite Resin; Indirect Restoration.

\section{RESUMO}

Objective: Este estudo teve como objetivo avaliar a influência do módulo de elasticidade de resinas compostas indiretas (RCI) na distribuição de tensão de um primeiro pré-molar superior restaurado. Materiais e métodos: Um modelo de elemento finito tridimensional (3D) de um dente com restauração mesio-ocluso-distal (MOD) foi utilizado. Foram simulados três RCI, alterando o módulo de elasticidade: 10, 15 e $20 \mathrm{GPa}$. Todos os materiais foram considerados isotrópicos, homogêneos, lineares e elásticos. Uma carga axial $(200 \mathrm{~N})$ foi aplicada na superfície oclusal através de uma esfera, e os nós da superfície externa das raízes foram fixados. Foi analisada a Tensão Máxima Principal no dente e na restauração. Resultados: De acordo com a análise, quanto menor for o módulo elástico da RCI, maiores são os valores de tensão de tração gerados no dente. Para a restauração, observou-se o oposto: quanto menor o módulo, menor a tensão de tração. Conclusão: Com as limitações deste estudo, é possível concluir que quanto maior o módulo de elasticidade do material restaurador, mais difícil será a deflexão das cúspides, mas, a fratura da resina será mais fácil.

\section{PALAVRAS-CHAVE}

Análise por elementos finitos; Resina composta; Restauração indireta. 


\section{INTRODUCTION}

T ndirect restorations using composite resin 1 or ceramic have the following advantages: excellent aesthetics reduced polymerization shrinkage, easy of obtaining contact point, and the ease of setting an appropriate occlusal anatomy $[1,2]$.

Dental ceramics have satisfactory aesthetics, color stability, wear resistance, and the possibility of conditioning with hydrofluoric acid, which increases the retention efficiency and biocompatibility [3]. However, as a disadvantage, ceramics exhibit susceptibility to fracture before cementation, wear potential of the antagonists (natural teeth) due to its high hardness [4].

Indirect composite resins (ICR) emerged with the aim to increase restoration durability [5]. With good values of mechanical properties, they started to be indicated for inlays, onlays, crowns and fixed partial denture [6,7]. Currently, ICR's are an excellent aesthetic alternative to ceramic due to the facility of their manufacture in the laboratory $[4,6]$, polymerization outside the mouth [8] and more dental preservation [9].

To simulate masticatory loads on teeth and restorations and also to evaluate the biomechanics of its resistance to fracture, finite element analysis (FEA) can be used [10]. This mathematical methodology consists in the evaluation of stress distribution trougth structures. Currently, several studies with this purpose take into consideration parameters of occlusal force and use of mesial-occlusal-distal preparations (MOD) in premolars $[3,7,11]$. When submitted to an occlusal load, the type of restorative material was shown to affect the deflection of the cusps [3]. In this way, the aim of this study was to evaluate the influence of different ICR's elastic modulus on the biomechanical behavior of MOD restorations.

\section{MATERIAL AND METHODS}

\section{Finite Element Analysis (FEA)}

To perform FEA, the elastic modulus (E) and the Poisson ratio (PR) of the resins used in this experiment were necessary. Three different resin was simulated, a resin with a low modulus (10 GPa), medium modulus (15 GPa) and high modulus (20 GPa), all with 0.3 Poisson's ratio. During preprocessing, a human premolar [3] with MOD cavity modeled in Rhinoceros CAD software (version 4.0SR8 McNell, North America, Seattle, WA, USA) was used. In order to make the simulation as real as possible, enamel $(E=84.1, P R=0.33)[12,14]$, dentin $(E=18.6$, $\mathrm{PR}=0.32) \quad[13,15]$ and pulp chamber were modeled. Finally, a Boolean union was used for linking these structures. The cavity preparation for an inlay was characterized by expulsive axial walls and pulp wall with no bevel at the proximal and occlusal margins (Figure 1). The tooth was imported in STEP format for ANSYS analysis software (ANSYS 17.2, ANSYS Inc., Houston, USA) (Figure 1). All materials were considered homogeneous, isotropic and linearly elastic. Mesh convergence test was used, and the ideal size of the elements was determined to $0.3 \mathrm{~mm}$. The three-dimensional mesh consisted of 175.278 nodes and 100.967 tetrahedral elements (Figure 1). To simulate the adhesion between the structures, the interface between dentin and resin was considered completely adhered. An axial load (200 N) was applied on both cusps through a ball $(10 \mathrm{~mm})$ moved in the $\mathrm{Z}$ axis $[3,14]$. The nodes of the external surface of the root were fixed to prevent the tooth from being intruded during loading (Figure 1). The stress distribution generated was calculated using Maximum Principal Stress (MPS) criteria on the tooth and restoration. 


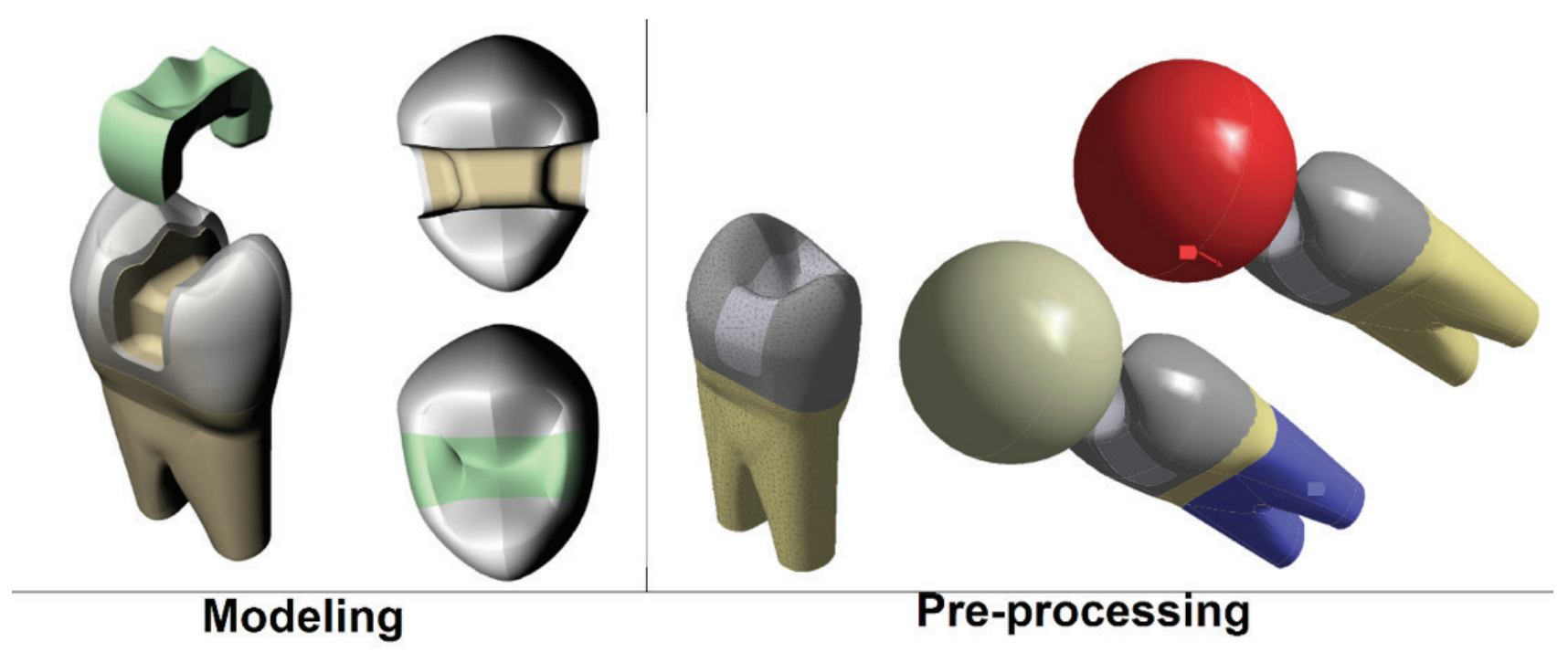

Figure 1-3D geometry created in computer aided designers software (Modeling) and after imported in computer aided engineering software (Pre-processing).

\section{RESULTS}

For restored tooth, all groups showed stress concentration on the loading points (cusps) and in the interface between enamel and restoration, however, the lower the elastic modulus of the restorative material, the higher the stress generated at the teeth. For restoration, the stress concentration was proportional to the elastic modulus of the material, suggesting that restorative materials with low modulus have the capacity to dissipate the masticatory forces (Figure 3). The stress peaks of the tooth and the restoration were plotted in a linear graph for quantitative comparison (Figure 4).

\section{DISCUSSION}

The main finding of the present study was establishingarelationbetweentheelasticmodulus (E) and the MPS following a linear model study [15] (Figure 4). Direct resins generate stresses due to polymerization shrinkage and limited conversion of the molecules [16,17]. These factors together contribute to microleakage in gingival walls [18-20]. Despite the fact that ICR do not present polymerization shrinkage that could stress the restoration interface, it was observed the presence of considerable amount of stress on internal walls of the cavity
(Figure 2), which allows us to assume that the stress concentration in this region is due to the differences in the elastic modulus of the material and the underlying dental substrate.

It has already been shown that the polymerization shrinkage increases the stress in the adhesive interface region since the high C-factor associated with cements with low elastic modulus tends to accumulate damages in this region [21]. As the 3D model of the present study has the cement of prosthesis simulated by the definition of a perfectly bonded contact between tooth and restoration, it can be assumed that the results express only the influence of the restorative material. The literature shows that the values of stress can be modified depending on the elastic modulus of the cement and the amount of material used during the cementation [11]. Although, the model has a simplified adhesive interface for an influence of the cementing agent. It is still possible to evaluate the biomechanics according to an influence of the restorative material as demonstrated by other studies with similar models $[3,22,23]$.

The observed values of ICR with high modulus were more homogeneous and presented less stress in the dental structure, indicating a better ability to withstand stress 

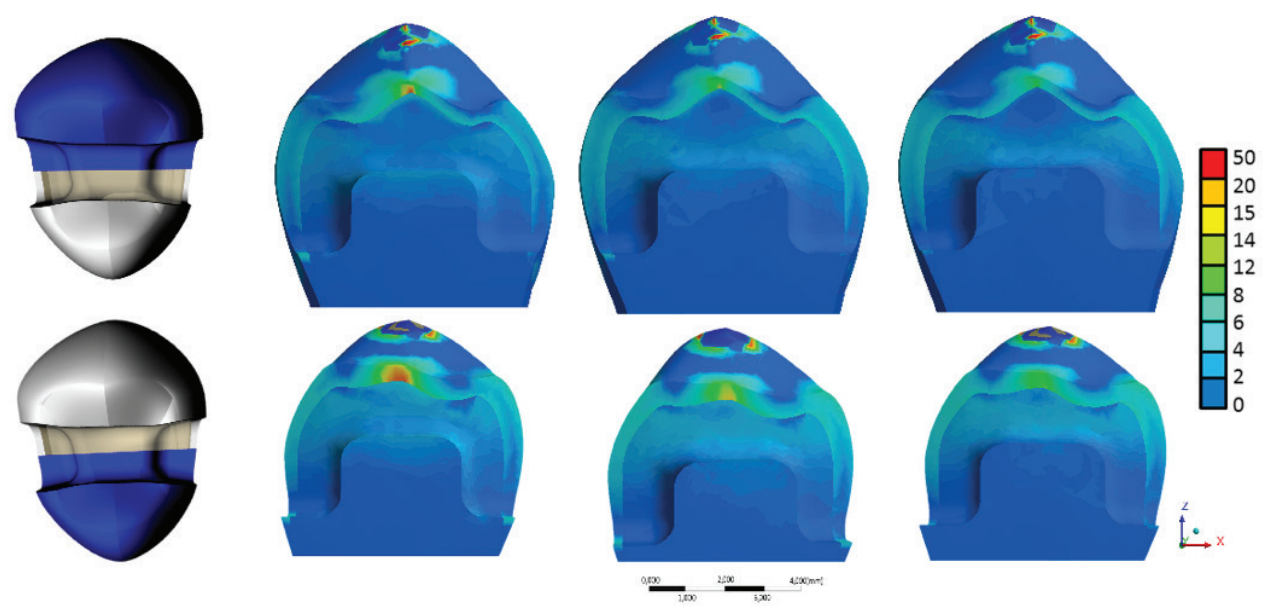

Figure 2 - Maximum Principal Stress (MPS) for restored tooth in sagittal cut, for buccal cusp in upper row and, lingual cusp in down row. Elastic modulus increase from left to right.
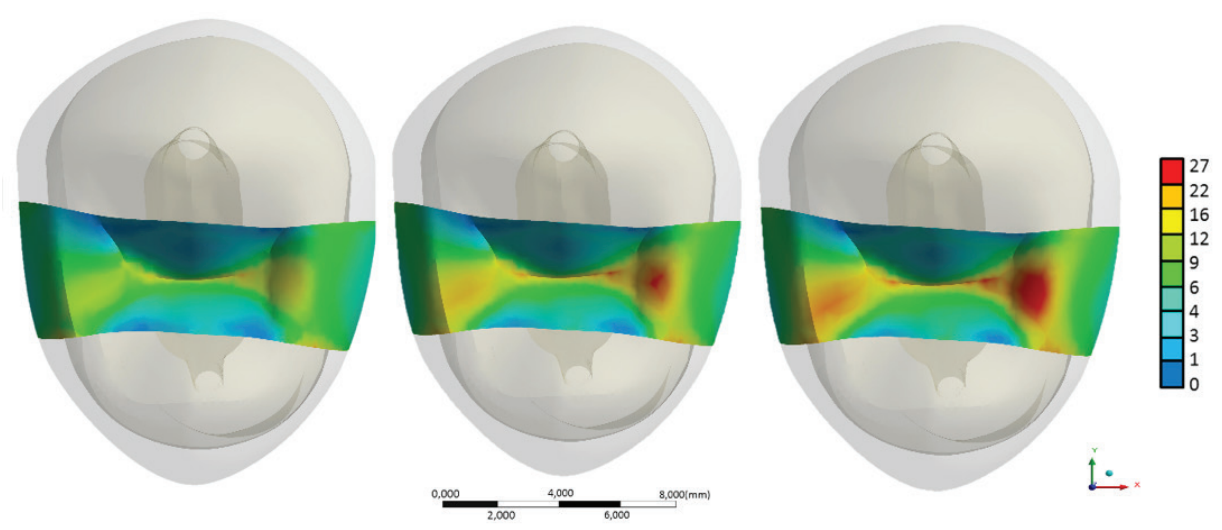

Figure 3 - Maximum Principal Stress (MPS) for restoration in oclusal view. Elastic modulus increase from left to right.

Restored Tooth

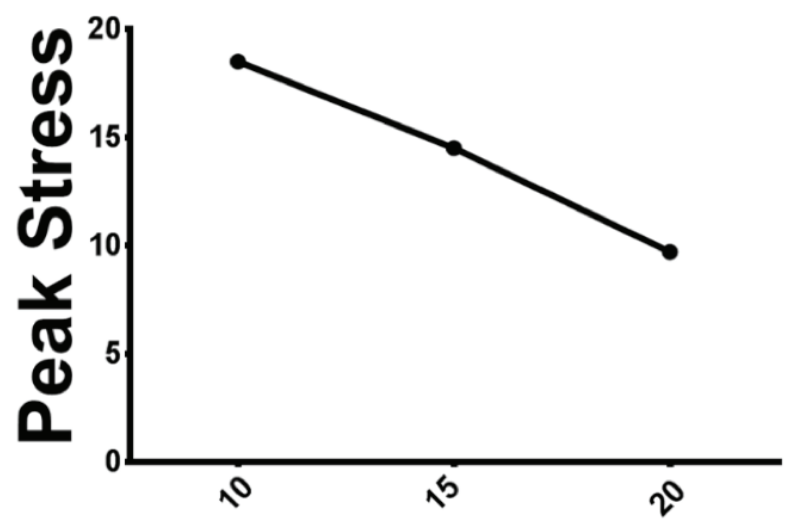

Elastic Modulus
Restoration

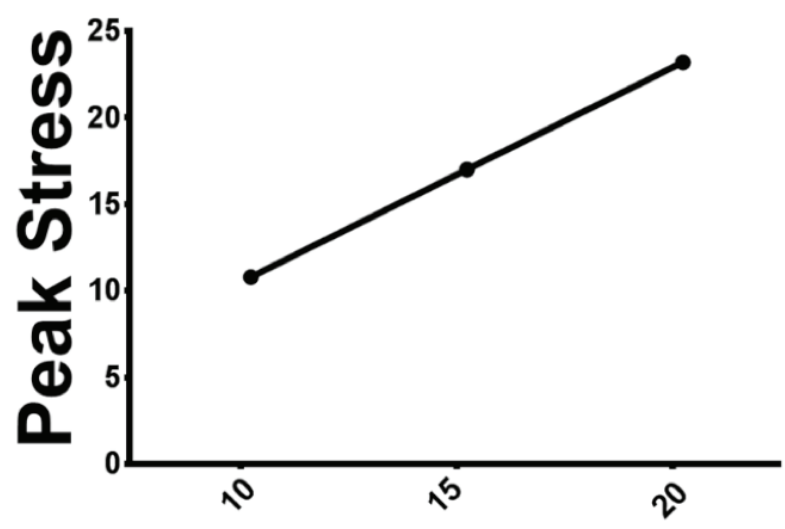

Elastic Modulus

Figure 4 - Linear graphs of Maximum Principal Stress (MPS) peak for A) restored tooth and B) restoration. 
during masticatory load. Thus, it is suggested that the high $\mathrm{E}$ of the material influenced in a lower dissipation of stress, preventing the bending of the cusps.

The application of $200 \mathrm{~N}$ is physiologic though, as observed by Burke [24] for the posterior region. With a sphere, the axial load can have slanting components in the cusps enhancing the probability of damage. The threedimensional model used in this FEA study can be validated due to in vitro studies evaluating the premolar behavior using strain gauges [25] or compressive test $[26,27]$, showed similar results, observing a higher concentration of stress on the lingual cusp for all groups (Figure 2).

In large posterior restorations involving the marginal ridges (MOD), FEA is quite elucidative [22].Therefore stress values observed in different materials can be determinant in maintaining the tooth integrity [11], and that, applied to more extensive the restoration, leads to higher bending of the cusps [28,29]. Observing Figure 2, ICR with lower elastic modulus concentrates more stress on the adhesive interface compared with higher modulus resins. Despite the concentration of more stress on restorations manufactured by stiffer materials, when fully cemented and adhered to tooth structure, they can resist the masticatory loads and tends to avoid less stress to the interface enamel /restoration, preventing unwanted deflection cusps (Figures 3 and 4). ICR with lower elastic modulus present more probability of adhesive failures, what can be confirmed through in vitro analysis that could confirm failure origins with simulated fatigue [3]. A finite element analysis is a cheaper, smart and adequate study tool to understand the biomechanical behavior of different resins. The in silico study can assist the understanding of different biomechanical conditions [30], and even if it is impossible to include all variables of the oral environment in a computational analysis, the joining conditions and the individual properties of the materials are already significant to evaluate your properties [31].

\section{CONCLUSION}

With the limitations of this study, it is possible to observe that indirect resins with high elastic modulus concentrate stress in the restoration, generating less strain at the cusps and protecting the tooth.

\section{REFERENCES}

1. Pegoraro LF, Valle AL, Araújo CRP, Bonfante G, Conti PCR, Bonachela V. Prótese Fixa. 7a série V17. São Paulo: Artes Médicas; 2004.

2. Mei ML, Chen YM, Li H, Chu CH. Influence of the indirect restoration design on the fracture resistance: a finite element study. Biomed Eng Online. 2016 Jan 8;15:3. doi: 10.1186/s12938-015-0115-4.

3. Costa A, Xavier T, Noritomi P, Saavedra G, Borges A. The influence of elastic modulus of inlay materials on stress distribution and fracture of premolars. Oper Dent. 2014 Jul-Aug;39(4):E160-70. doi: 10.2341/13-092-L.

4. Touati B. The evolution of aesthetic restorative materials for inlays and onlays: a review. Pract Periodontics Aesthet Dent. 1996 Sep;8(7):657-66; quiz 668.

5. Borges ALS, Borges AB, Barcellos DC, Saavedra GSFA, Paes Junior TJA, et al. Avaliação da resistência flexural e módulo de elasticidade de diferentes resinas compostas indiretas. RPG Rev Pós Grad. 2012;19(2):50-6.

6. Nandini S. Indirect resin composites. J Conserv Dent. 2010 0ct;13(4):184-94. doi: 10.4103/0972-0707.73377.

7. Alshiddia IF, Aljinbaz A. Fracture resistance of endodontically treated teeth restored with indirect composite inlay and onlay restorations - An in vitro study. Saudi Dent J. 2016 Jan;28(1):49-55. doi: 10.1016/j.sdentj.2015.09.001.

8. Saridag S, Helvacioglu-Yigit D, Alniacik G, Özcan M. Radiopacity measurements of direct and indirect resin composites at different thicknesses using digital image analysis. Dent Mater J. 2015;34(1):13-8. doi: 10.4012/dmj.2014-181.

9. Özcan M, Koekoek W, Pekkan G. Load-bearing capacity of indirect inlay-retained fixed dental prostheses made of particulate filler composite alone or reinforced with E-glass fibers impregnated with various monomers. J Mech Behav Biomed Mater. 2012 Aug;12:160-7. doi: 10.1016/j.jmbbm.2012.02.023.

10. Dal Piva AMO, Tribst JPM, Souza ROAE, Borges ALS. Influence of Alveolar Bone Loss and Cement Layer Thickness on the Biomechanical Behavior of Endodontically Treated Maxillary Incisors: A 3-dimensional Finite Element Analysis. J Endod. 2017 May;43(5):791-5. doi: 10.1016/j.joen.2016.11.020.

11. Ausiello P, Rengo S, Davidson CL, Watts DC. Stress distributions in adhesively cemented ceramic and resin-composite Class II inlay restorations: a 3D-FEA study. Dent Mater. 2004 Nov;20(9):862-72.

12. Singh SV, Bhat M, Gupta S, Sharma D, Satija H, Sharma S. Stress distribution of endodontically treated teeth with titanium alloy post and carbon fiber post with different alveolar bone height: A three-dimensional finite element analysis. Eur J Dent. 2015 JulSep;9(3):428-32. doi: 10.4103/1305-7456.163228. 
13. Madfa AA, Kadir MR, Kashani J, Saidin S, Sulaiman E, Marhazlinda $\mathrm{J}$, et al. Stress distributions in maxillary central incisors restored with various types of post materials and designs. Med Eng Phys. 2014 Jul;36(7):962-7.

14. Magne P. Efficient 3D finite element analysis of dental restorative procedures using micro-CT data. Dent Mater. 2007 May;23(5):53948. Epub 2006 May 26

15. Asmani M, Kermel C, Leriche A, Ourak M. Influence of porosity on Young's modulus and Poisson's ratio in alumina ceramics. J Eur Ceram Soc. 2001;21(8):1081-6.

16. Hilton TJ. Can modern restorative procedures and materials reliably seal cavities? In vitro investigations. Part 2. Am J Dent. 2002 Aug;15(4):279-89.

17. Ferracane JL, Mitchem JC. Relationship between composite contraction stress and leakage in Class V cavities. Am J Dent. 2003 Aug;16(4):239-43.

18. Eakle WS, Nakamoto DK. Microleakage in MOD resin composite with three dentin bonding agents. Dent Mater. 1989 Nov;5(6):361-4.

19. Prati C, Tao L, Simpson M, Pashley DH. Permeability and microleakage of Class II resin composite restorations. J Dent. 1994 Feb;22(1):49-56.

20. Gordan VV, Mjör IA. Short- and long-term clinical evaluation of post-operative sensitivity of a new resin-based restorative material and self-etching primer. Oper Dent. 2002 NovDec;27(6):543-8.

21. Cornacchia TM, Silva GC, Magalhaes CS, Moreira AN, Las Casas EB Analysis of stresses during the polymerization shrinkage of selfcuring resin cement in indirect restorations: a finite-element study. Indian J Dent Res. 2014 Nov-Dec;25(6):755-7. doi: 10.4103/09709290.152192.

22. Gallardo DCD, Mera KF. Restauraciones indirectas: análisis comparativo en elemento finito de inlays y overlays en premolares con cavidades MOD restauradas con cerómero y cerámica. Odontología. 2015;17(1):117-25.
23. Kantardžić I, Vasiljević D, Blažić L, Lužanin 0. Influence of cavity design preparation on stress values in maxillary premolar: a finite element analysis. Croat Med J. 2012 Dec;53(6):568-76.

24. Burke FJT. Tooth fracture in vivo and in vitro. J Dent. 1992 Jun;20(3):131-9.

25. Pereira FA, Zeola LF, de Almeida Milito G, Reis BR, Pereira RD, Soares PV. Restorative material and loading type influence on the biomechanical behavior of wedge shaped cervical lesions. Clin Oral Investig. 2016 Apr;20(3):433-41. doi: 10.1007/s00784-015-1523-3. Epub 2015 Jul 11.

26. Lin CL, Chang YH, Liu PR. Multi-factorial analysis of a cuspreplacing adhesive premolar restoration: A finite element study. $\mathrm{J}$ Dent. 2008 Mar;36(3):194-203. doi: 10.1016/j.jdent.2007.11.016. Epub 2008 Jan 24.

27. Durand LB, Guimarães JC, Monteiro Junior S,Baratieri LN. Modeling and validation of a 3D premolar for finite element analysis. Rev Odontol UNESP. 2016;45(1):21-6. Epub January 19, 2016.

28. Lin CL, Chang WJ, Lin YS, Chang YH, Lin YF. Evaluation of the relative contributions of multi-factors in an adhesive MOD restoration using FEA and the Taguchi method. Dent Mater. 2009 Sep;25(9):1073-81.

29. Sandu L, Florin T, Sorin P. Finite element analysis of MOD prosthetic restored premolars. Proceedings of the 13th WSEAS international conference on Mathematical and computational methods in science and engineering. World Scientific and Engineering Academy and Society (WSEAS), 2011.

30. Trivedi S. Finite element analysis: A boon to dentistry. J Oral Biol Craniofac Res. 2014 Sep-Dec;4(3):200-3. doi: 10.1016/j. jobcr.2014.11.008. Epub 2014 Dec 4.

31. Dejak B, Młotkowski A, Langot C. Three-dimensional finite element analysis of molars with thin-walled prosthetic crowns made of various materials. Dent Mater. 2012 Apr;28(4):433-41. doi: 10.1016/j. dental.2011.11.019. Epub 2011 Dec 29.

\section{João Paulo Mendes Tribst (Corresponding address)}

Instituto de Ciência e Tecnologia, Universidade Estadual Paulista (UNESP), Av. Eng. Francisco José Longo, n ${ }^{\circ} 777$ Jardim São Dimas. 12245-000 São José dos Campos; SP - Brasil. Date submitted: 2017 Jun 19 joao.tribst@ict.unesp.br Accept submission: 2017 Aug 11 